\title{
Arte da precariedade, cultura da alteridade. Thomas Hirschhorn e Georges Bataille
}

\author{
Osvaldo Fontes Filho'
}

Resumo: Este artigo focaliza a figura do artista engajado da atualidade, personificado por Thomas Hirschhorn, cuja obra trabalha nos limites da precariedade material. Seus trabalhos privilegiam o diálogo com o Outro, em empenho por repolitizar a arte. Procura-se caracterizar o artista-produtor em seu apelo a Georges Bataille (1897-1962), teórico da transgressão que preconizou para a modernidade um dispêndio insensato de formas e energia como contrafação dos mecanismos regrados do consumo moderno. A reflexão explora, por fim, os recursos da cultura da alteridade absorvida por uma arte política, e os riscos que incorre de formalismo e de condescendência etnográfica no trato com os marginalizados da atualidade.

Palavras-chave: Precariedade. Alteridade. Arte e política. Pós-modernidade.

\section{Art of precariousness, culture of otherness. Thomas Hirschhorn and Georges Bataille}

\begin{abstract}
This article focuses the figure of the engaged artist of our times, personified by Thomas Hirschhorn, whose practices intends to work within material precariousness. His works privilege dialogue with the Other, in an effort to repoliticize the art. It tries to characterize producer artist in his appeal to Georges Bataille (1897-1962), a transgression theorist who advocated for modernity an unreasonable expenditure of shapes and energy as a counterpart of the regulated mechanisms of modern consumption. This paper explores the resources of a culture of otherness when absorbed by a political art, and how it faces the risks of formalism and of ethnographic condescension in dealing with the marginalized living.
\end{abstract}

Keywords: Precariousness. Otherness. Art and politics. Postmodernity.

I Mestre e Doutor em Filosofia pelo Departamento de Filosofia da FFLCH-USP, com pós-doutorado na Unesp de São José do Rio Preto, desenvolveu durante anos pesquisas nas áreas de Ciências da Linguagem e Filosofia da Arte na Université François Rabelais de Tours/França, bem como no Centre d'Histoire et Théorie de I'Art da École de Hautes Études en Sciences Sociales de Paris/França. Professor Doutor no Departamento de História da Arte da Universidade Federal de São Paulo - Estrada Caminho Velho, 333. Pimentas, 07252-312. E-mail: osvaldo.fontes@unifesp.br. ORCID: https://orcid.org/0000-0002-2358-3902. Lattes iD: http://lattes.cnpq.br/4167849706894566. Guarulhos, Brasil. 
Os termos "arte política", "arte engajada”, "artista político" são hoje de uso corrente. Essas simplificações e atalhos estão há muito ultrapassados. São classificações fáceis, sumárias e preguiçosas. [...] Como artista, é preciso se engajar no trabalho e com o trabalho. Não há outra possibilidade senão um compromisso total se quisermos conseguir algo com a arte. Isso se aplica a qualquer arte. Toda arte é engajada. Hoje há uma grande confusão em relação à questão do que seria "Política". Estou interessado apenas pela verdadeira "Política", a política que implica e faz a pergunta: qual é a minha posição? qual é aquela do outro? O que eu quero? O que o outro quer?

(Thomas Hirschhorn, Faire de l'art politiquement: qu'est-ce que cela veut dire?, 2008)

\section{Sacrifício da forma}

A verdade sempre foi entendida por Georges Bataille como um "violento desmentido" a ser extraído de alguma condição nauseabunda: verdade extorquida, embaraçosa, vergonhosa, mesmo porque toda verdade guarda um pouco das impurezas de onde surge. É, pois, com o mesmo "prazer cínico" com o qual considera "palavras que arrastam qualquer coisa nossa até a lata de lixo" que Bataille endereçava-se a seus pares, em 1931, a fim de denunciar a "submissão habitual dos caracteres e dos costumes" (BATAILLE, 1970d, p.236). Essa denúncia marcava o fim de um período particularmente virulento de polêmicas e diatribes no qual Bataille personificou, à frente da revista Documents, o lado mais radicalmente avesso das vanguardas às acomodações formais e intelectuais. Condenado por seu radicalismo incondicional ao "mais triste isolamento", aquele que mais tarde se dirá colérico em face de "furtivas concessões" não via doravante como interlocutores senão "homens [...] decompostos, tornados amorfos, expulsos com violência para fora de toda forma" (BATAILLE, 1970b, p.54-55), os únicos, segundo ele, capazes de partilhar de um então urgente espírito político de defecção. A atitude traia uma posição que se queria "intransigente" e "indefensável", aquela de incriminação das formas usuais. Uma posição que se apoiava na evidência de que os tempos eram de uso leniente de formas inofensivas, tempos de emasculação das representações do homem, de parvoíces e delírios surreais, momento em que imperavam condenáveis transposições poéticas. Sua convicção: suplantar os interditos, "escândalo do espírito", estaria ao alcance somente de uma selvageria da forma, capaz de dilapidar os sentidos conformados, constritos a suas idealidades.

O engajamento que Bataille assim premeditava concorria para o que ele acreditava de fato capaz de desvelar a condição humana: o gasto sem compensação, a prodigalidade sem medida, a deperdição sem sentido. Em oposição aos conformismos mais vergonhosos, às palavras coaguladas, ele propunha um exercício sacrificial da forma, modo de se haver com uma congênita necessidade de tudo revirar, até o antro informe das coisas. 


\section{Esgotamento da forma}

Em 1996, o Centre Georges Pompidou de Paris abrigou uma exposição antológica intitulada Informe: mode d'emploi, comissionada por Rosalind Krauss e Yve-Alain Bois. Em torno dos protocolos bataillianos do inconformismo, ambos propunham uma "leitura [alternativa] da arte moderna por meio do informe" (KRAUSS \& BOIS, 1996a, p.9). Na verdade, mais que uma leitura a se acrescentar a tantas, a intenção apregoava considerável peso crítico: ela ofereceria uma "terceira via de acesso ao campo estético da modernidade", para além da antinomia da forma e do conteúdo (lógica binária). O que se entendia deslegitimar era uma história da arte moderna como sequência triunfal de conquistas formais iniciadas com Manet e sua "indiferença para com o objeto", conquistas cujo derradeiro avatar teria sido o retorno ao expressionismo em pintura nos anos 80 .

Em sua empreitada, Krauss e Bois não perdiam de vista a natureza performativa do informe. Razão porque eles entendiam "pôr a trabalhar", literalmente, o informe enquanto "ato dessublimatório de agressão" para além de toda experiência puramente formal (KRAUSS \& BOIS, 1996a, p.18 e 14, respectivamente). O engajamento traia assim seu escopo central: a contrafação da leitura greenberguiana do modernismo como uma "linha progressiva rumo ao expressionismo abstrato" (KRAUSS \& BOIS, 1996a, p.25). Para tanto, cumpria explorar os possíveis usos do pensamento do informe - operação, mais que tema, substância ou conceito - em uma leitura da produção artística do século XX, com particular foco no período de construção e desconstrução do modernismo, 1930-1975, período de triunfo da arte moderna baseada na doutrina greenberguiana das descobertas formais. Formless. A User's Guide definia, por fim, seu ambicioso escopo de resistência crítica e desafio à versão oficial da história da arte moderna.

Como operação provocadora para alterar o alto modernismo e rebaixar sua hegemonia, a estratégia ficava clara: retomar o movimento que assumiu ao longo do modernismo formas infinitamente metamórficas. Donde as convocações: dos anos 20-30, os rotorelevos de Marcel Duchamp, as colagens com sucatas de Picasso, os papéis rasgados de Jean Arp, as esculturas horizontais de Giacometti; dos anos 60, os grafites de Cy Twombly, os detritos de Robert Morris, as pinturas oxidadas de Warhol. Uma vez elencados os avatares, a operação reconhecia na figura de Bataille um particular peso conceitual para uma segura "reviravolta histórica" (KRAUSS \& BOIS, 1996b, s.p.). 
O que a principio motivou os curadores a vir ter com o motivo do informe parece ser o fato, como se disse, de que este possui virtude heurística, consiste em uma "operação". O informe é, sobretudo, operador de rejeição do conceito como lugar agregativo. Uma das tantas "manchas de tinta" a que se referia Bataille em "Le langage des fleurs" contra os floreios da retórica usual, o informe incorre em um constante non seguitur, ou seja, aponta para a inconclusão e a desagregação.

Assim, nas obras então elencadas as formas operam claro rebaixamento, por derrisão de toda plenitude formal ou mesmo por regressão a formas pueris. Caos, desorientação e entropia - as três frentes de releitura do modernismo em Formless. A User's Guide - parecem reorientados para desclassificar as unidades constitutivas da história da arte: estilo, tema, cronologia, corpo da obra. Não surpreende, pois, que comparecessem os monocromos asfálticos e a lama mofada na Dirt Painting de Robert Rauschenberg ou os plásticos queimados de Alberto Burri, exemplares de uma matéria que não pode ser "reabsorvida pela imagem". Ainda, as obras kitsch de Fontana ou Manzoni, por evocarem um mau gosto que o discurso modernista sempre entendeu escamotear. Quanto à entropia, processo de desagregação e degradação, os curadores contavam com Duchamp e seu Elevage de poussière, com Jean Arp e seus papéis recortados, com Raymond Hans, Jacques Villeglé e François Dufrêne e suas "descolagens"; ou, ainda, com Arman e suas acumulações de refugos ou mesmo com as fotografias de Ruscha da descontinuidade da paisagem urbana: artistas que de um modo ou de outro mostram que tudo se desfaz, se liquefaz, decai em restos. Todos contra-exemplos, pela irreversibilidade entrópica do tempo e do espaço, da concepção modernista da arte como atividade sintetizadora e da obra como totalidade fechada. Todos exemplos de operações de esgotamento da forma.

Não escapava, por fim, a Rosalind Krauss o fato que a soberania na arte engloba "forças de exclusão no campo social" (KRAUSS \& BOIS, 1996a, p.249). O que implicava, entenda-se, convocar forças bem distantes daquelas comumente abrigadas nas galerias de arte. Ainda que a exposição do Beaubourg guardasse a liturgia da oficialidade artística (afinal, os nomes convocados seguiam sendo aqueles do panteão das vanguardas históricas), a proposta de desmontar a história da modernidade artística, operação em torno do informe, constituia um processo de "criação do diferente, do desviado, do não generalizável, do não assimilável" (KRAUSS \& BOIS, 1996a, p.252). 


\section{Resgate da Forma}

O pós-modernismo parece ter remetido a uma época heróica da modernidade esse programático esgotamento das formas, dando lugar a uma miscelânea generalizada dos signos e das formas. Talvez seja caso, então, de investigar nesse contexto o que motiva o artista suiço Thomas Hirschhorn a resgatar a Forma, elevada agora a condição transcendental de uma produção artística que se quer desviada dos esquemas usuais de reflexividade formal e de criticalidade da arte contemporânea.

Hirschhorn é um artista que se recusa a entrar no quadro estético corrente, a programar uma demonstração pública de insatisfação pelo poder estatal ou pelas intolerâncias ideológicas, ou a sujeitar os espectadores à aura reglamurizada do artista, ou ainda a experimentar novos modos de vínculo social por força de alguma artificialidade cenográfica. Em seus trabalhos, o artista não tem a pretensão de desvelar identidades subalternas, informar sobre o estado da sociedade, reconciliar o público com a vida social. É certo que ele persiste em questionar as maneiras correntes em suas discriminações dos problemas suscitados pelas partilhas sociais. É certo que ele persiste em procurar pela implicação em sua arte, afeita aos refugos e descartes da sociedade. De seu público, que ele chama "público não exclusivo", desinteressado a priori do mundo das artes, faz parte talvez os "homens [...] decompostos, tornados amorfos, expulsos com violência para fora de toda forma" a quem Bataille se endereçava em seu tempo. Entretanto, há nos trabalhos de Hirschhorn uma marginalidade não buscada, o aceno a uma destinação natural da arte junto ao que Bataille chamaria um "baixo materialismo", formas rebaixadas, desvalorizadas.

Em Hirschhorn, uma interpretação (re)inventiva do mundo se faz por uma estética da ruína e da destruição (em Re-Sculpt, 2018), da catástrofe (em Collapse, 2018), do desastre (em Concordia Concordia, 2013), do excesso e da saturação (em Too Too-Much Much, 2010) (figs. 1, 2 e 3). A cada feita, ele faz uso, comumente caótico, de materiais de fatura rústica ou industrial: madeira, papelão, plástico, acrílico, fita adesiva, tinta spray, fio elétrico, lâmpadas fluorescentes, fotocópias, manequins, mesas com pregos e parafusos, ferramentas, megafones, banners, cavaletes, livros e impressos em geral. Em busca da rejeição de pensamentos pré-formatados e interrogando sobre o acesso à informação consensual, Hirschhorn transforma suas premissas sociopolíticas em objetos que funcionam por associação simbólica, retirados de seu contexto usual e tornados materialidades sígnicas. A linguagem é, 
comumente, aquela das colagens e dos grafites - com referencias a Kurt Schwitters, Joseph Beuys e Andy Warhol -, em favor de dispositivos cenográficos de fatura propositadamente grosseira, pelos quais é objetivada uma espacialização anárquica de informações visuais e gráficas.

Nessa processualidade, por flertar com urgências comumente pouco reconhecidas, a Forma não investe operações de estetização, mas é integridade soberana: "não divisível, inegociável e até mesmo não discutível [...] como um átomo ou um núcleo - isso é incondicional" (HIRSCHHORN, 2015).

Em Stand Alone (2007), Hirschhorn idealiza 4 salas para abrigar o que afirma ser "campos de formas e de força": "Amor", "Filosofia", "Estética" e "Política". Trata-se de dar forma, mais que fazer uma forma, discrimina o artista. A diferença é de peso, e retira as iniciativas do artista de qualquer formalismo

Figura 1

Thomas Hirschhorn Re-Sculpt, 2018 Ming Contemporary Art Museum, Shanghaï (China) Fonte: http://www. thomashirschhorn. com/re-sculpt/

Figura 2

Thomas Hirschhorn, 2013. Concordia, Concordia, Gladstone Gallery, N. Y. Fonte: http://www. thomashirschhorn. com/concordia-concordia-2/

Figura 3 Thomas Hirschhorn, 2010. Too too much much, Galerie Chantal Crousel, Paris. Fonte: https:// publicdelivery.org/ thomas-hirschhorntoo-too-much-much/
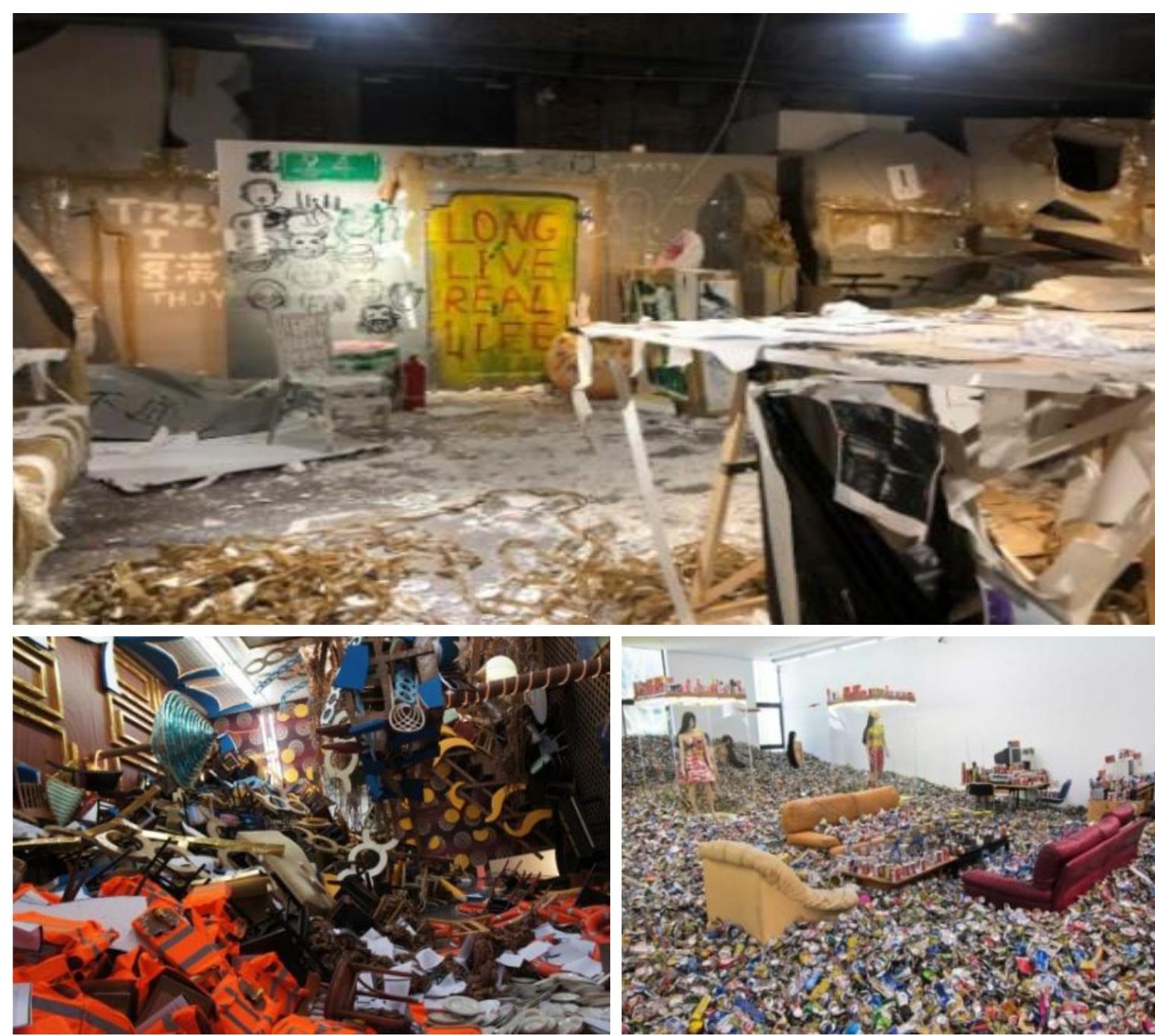
tutelado pelos caminhos balizados de uma arte creditada junto à denuncia social. O que se coloca é, antes, da ordem de um gesto de resistência, de uma tomada de posição.

Dar forma significa - ao contrário de criar uma forma - ser um com essa forma. Eu tenho que ser essa forma, eu sou essa forma. Isso significa levantar alto essa forma, isso significa afirmar e defender essa forma, contra tudo e contra todos. Trata-se de suscitar a questão da forma e querer responder dando forma, pela forma. Quero enfrentar o grande desafio artístico: como criar uma forma que se posicione? Como criar uma forma que resista aos fatos? (HIRSCHHORN, 2010, s.p.)

A questão da forma não é, pois, uma questão interna às processualidades artísticas. Não há especificidade dos meios de expressão a reivindicar. Dar forma é tomar posição. E tomar posição, analisou recentemente Didi-Huberman (2017, p.15), é afrontar algo ao mesmo tempo em que "contar com tudo aquilo de que nos afastamos". Assim, à questão da forma importa tanto uma afirmação de vontade quanto uma admissão de temores e incapacidades. Tornada concreta nas instalações, como em Stand alone, pelo trabalho com materiais de fatura pobre e formalmente desqualificados, a forma espacializa ("uma colagem no espaço", explica Hirschhorn) questões tais como: "Onde estou? O que eu quero?". Ou então: "Como posso assumir uma posição? Como posso dar uma forma a essa posição? E como posso por meio desta forma criar verdade - para além dos hábitos políticos, estéticos e culturais?" (HIRSCHHORN, 2010, s.p.). São assim criadas as condições para um "direto diálogo ou confrontação", um esforço de implicação, com a suposta urgência para tanto, junto à "incompreensibilidade e obscuridade do mundo" (HIRSCHHORN, 2007, s.p.).

Em Stand alone, as paredes são cobertas pelo que Hirschhorn chama "poesia noticiosa": fragmentos de textos da mídia que, à primeira vista, parecem ser pixos ordinários confrontam os espectadores, visceralmente, como reflexos desajeitados da realidade errática que se vivencia no presente (fig. 4). As ideias são assim colocadas em diálogo umas com as outras e as associações se forjam, materialmente, através do espaço, desconectadas de qualquer contexto histórico. O display (Hirschhorn renega o termos "instalação", pertencente ao "mundo da arte"), ao solicitar a experiência incorporada dos espectadores, para além dos hábitos políticos, estéticos e culturais, renega um público iniciado nas artes: a proposta de vir ter com uma realidade não formalizada por protocolos artísticos trabalha pela cumplicidade de um "público não exclusivo" - o público de arte, assume Hirschhorn, é "o pior 
do mundo, educado em excesso, conservador, ele está lá para criticar e não entender e, além disso, nunca se diverte". Trata-se de propor um grande rebatimento das abstrações artísticas sobre um plano de composição, caótico por princípio, onde vida e forma se confundem.

Quero trabalhar no mundo absoluto, no seu caos, na sua complexidade, na sua incomensurabilidade e na sua falta de clareza. Eu quero tocar o núcleo duro, o caos. Eu quero estar na briga. Só posso dar forma a algo se encarar a realidade de maneira positiva, positiva diante do núcleo duro da realidade (HIRSCHHORN, 2010, s.p.).

Figura 4

Thomas Hirschhorn. Stand Alone, 2016 The Mistake Room, Los Angeles (USA)

Fonte: http://www. thomashirschhorn. com/stand-alonethe-mistake-roomlos-angeles/

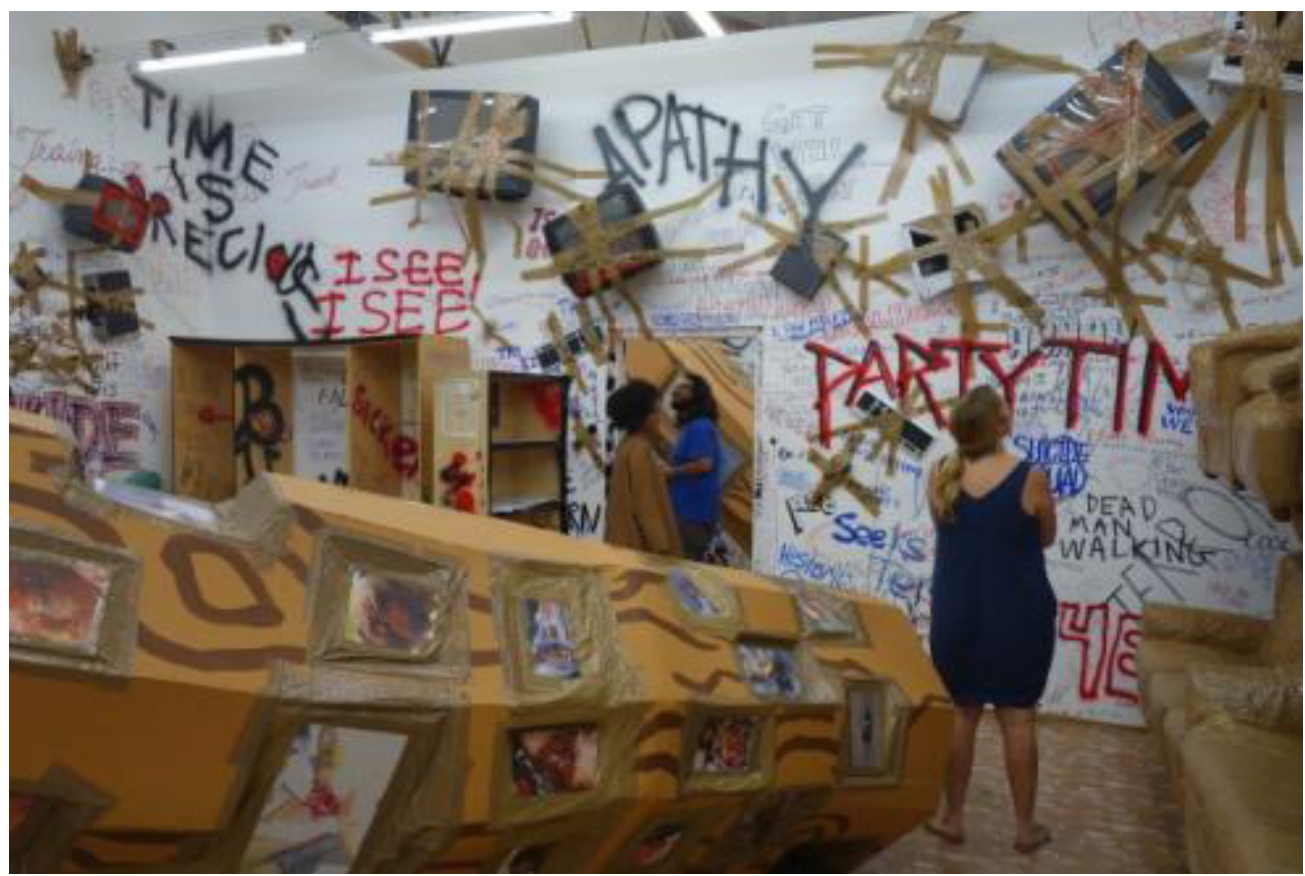

\section{Monumento Bataille}

Proposto para a Bienal de Kassel em 2002, o Monumento Bataille se faz no contrapé das oficialidades. Evita o centro da cidade ou os espaços reservados para a arte, e imigra para um subúrbio decadente da cidade alemã, habitada por imigrantes turcos. Hirschhorn assume ali, plenamente, a figura do produtor. Apela para uma instituição de enquadramento de jovens delinquentes, para os quais solicita a colaboração remunerada, assim como dos moradores locais, desempregados em sua maioria. Não iniciados nas artes, os colaboradores/interlocutores de Hirschhorn são convidados a partilhar uma aventura 
coletiva: erguer um espaço temporário de exposição e frequentação em torno da figura de um escritor e pensador desconhecido da comunidade. O projeto visa dar a essa comunidade um regime diferenciado de troca de tempo e de energia. Dádiva que se sustenta de um espírito de empatia ante esse outro, pobre e estrangeiro às coisas da arte contemporânea. Assim, a presença do artista não se faz aurática, mas operativa, cotidiana, nas reuniões preparatórias, nos cursos, na montagem, nas exposições e na desmontagem do monumento. "Presença e Produção": com esse apelativo, Hirschhorn caracteriza uma linha de conduta inflexível, que não se vê contemplada nas nomenclaturas usuais: community art, participative art, educational art ou aesthetic relational art (HIRSCHHORN, 2009-10).

Composto por edificações em tapumes de madeira (que se assemelham a abrigos para refugiados), o Monumento Bataille abrigava uma biblioteca, um espaço de exposição, uma lanchonete, um estúdio de TV, um local para oficinas, uma escultura (área de repouso e de incentivo a jogos infantis). Tudo ali se opõe à demagogia do monumento, a sua dimensão consensual (fig. 5). Hirschhorn deplora as memorabilia promovidas pela oficialidade institucional. No espaço de convivência, referência aos poetas turcos reprimidos à época pelo Estado permite denotar a intenção contestatória do artista.

Figura 5 Thomas Hirschhorn.

Monument Bataille, 2002. Kassel. Fonte: br.pinterest.com/ pin/33136648 $5058175381 /$

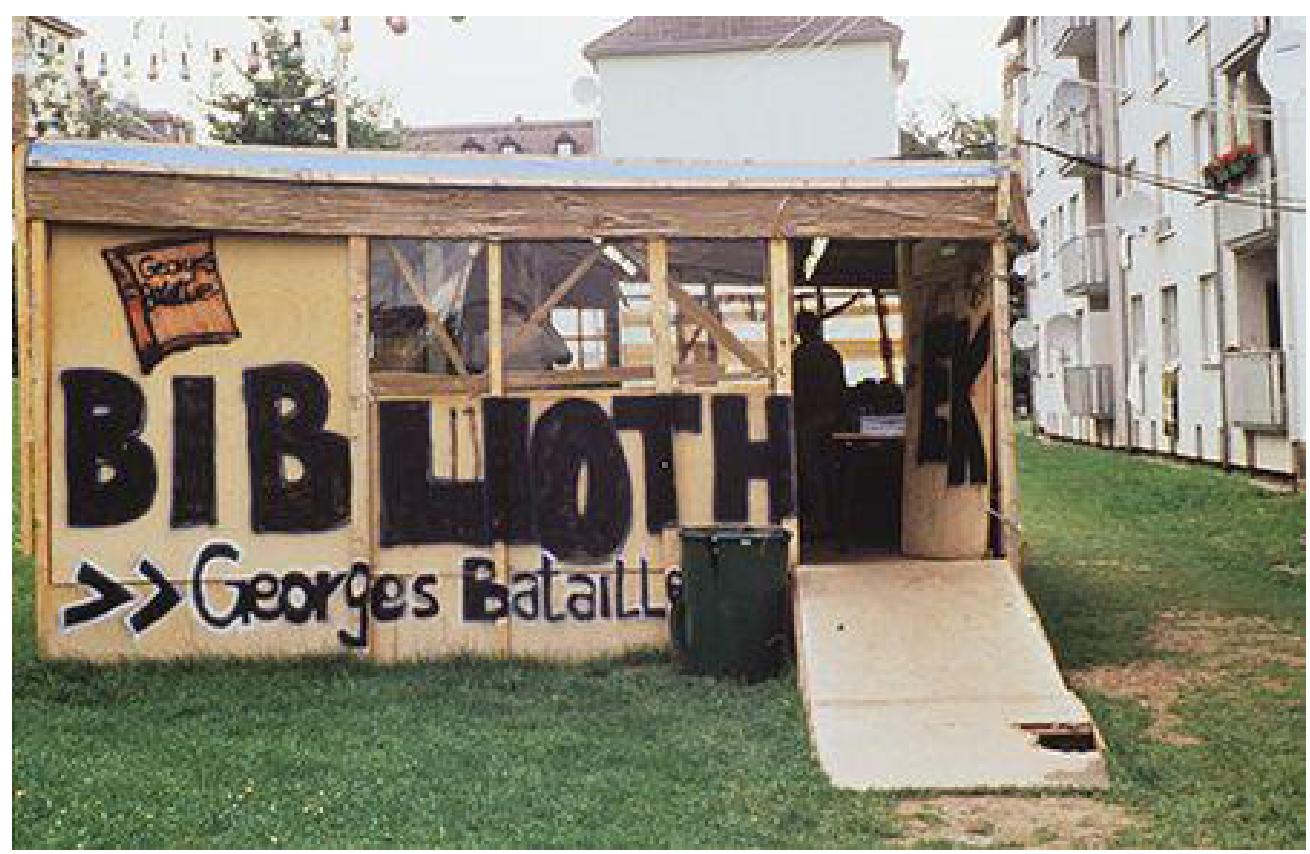


Em meio à exposição, fotografias de corpos mutilados, desmembrados, apontam para a violência social e histórica. Elas remetem, ainda, às figuras sacrificiais do panteão batailliano, sucedâneo às anatomias de consensualidade que comumente a pedagogia de massa da imageria comercial ajuda a referendar. $\mathrm{O}$ artista e o escritor, obcecados pela morte violenta, procuram, pois, a comunidade capaz de superar o mal dos conformismos.

Na base da iniciativa do Monumento Bataille reside a noção de dispêndio exposta em La Part maudite (1933). Na perspectiva de Bataille, um dispêndio das formas presta-se a deslegitimar as "grandes ideias diretivas" que sustentam a consciência de autoridade - de que são particularmente emblemáticas as formas arquiteturais, mas também as formas de governabilidade e sociabilização. O Bataille de Hirschhorn é aquele que abriga tudo quanto seja abertamente rejeitado como baixo pelo universo arquitetado da razão: modo de deslegitimar o universo alto e suas insidiosas sublimações. A contestação batailliana mostra a Hirschhorn que a "heterogeneidade subjetiva dos elementos particulares é praticamente a única concreta" (BATAILLE, 1970b, p.66), e que é possível trabalhar essa heterogeneidade em chave política a favor do "reviramento da ordem estabelecida" por meio das baixas camadas sociais. A ação revolucionária de Bataille, não o ignora Hirschhorn, é aquela de uma "velha toupeira" em escavação por subsolos repugnantes (BATAILLE, 1970c, p., p.93).

Não deixa de ser audacioso propor a uma comunidade de excluídos sociais uma apologia de "concretudes" tais como a atividade sexual, a "violação excessiva do pudor", a morte e o "interesse libidinoso pelo estado cadavérico", os tabus, a antropofagia ritual, os sacrifícios, os gastos ruinosos, o riso e as lágrimas, o êxtase. Tudo quanto seja tratado como um "corpo estranho", assim como todas aquelas forças radicalmente subterrâneas e subversivas encontram em Bataille, se não um sentido concertado, ao menos seu valor de uso maior enquanto "satisfações violentas implicadas pela existência social” (BATAILLE, 1970b, p.63)

Os grandes textos de sociologia política dos anos 1930 na revista Acéphale, e a partir de 1937 no coletivo de vanguarda Collège de Sociologie, tinham por leitmotiv o (anti)conceito de heterologia. Ele se prestava a contradizer todo modelo organicista de sociedade em favor de uma impossível recomposição "comunitária" (BATAILLE, 1995, p.36), com a severa implicação de uma dissolução sacrificial e uma alienação da identidade individual. "Os homens reunidos para o sacrifício e para a festa, sustentava Bataille (1995, p.809), satisfazem a necessidade que experimentam de despender um de- 
masiado-pleno (trop-plein) vital”. A dilaceração do sacrifício, que abre para uma comunhão festiva na perda, entende ser uma "dilaceração libertadora", base de um efetivo engendramento social.

Essa perspectiva mostra ao "produtor" Hirschhorn como nas sociedades modernas prevalecem os processos de apropriação, os objetos convertidos em "séries classificadas de concepções ou ideias", dispostos para o consumo "de forma medida e racional". Processo de homogeneização ao qual Bataille opunha um "consumo sacrificial", capaz de preservar o caráter heterogêneo do objeto da excreção. Ao heterogêneo corresponde um "pensamento dos corpos estranhos" pondo em pauta fenômenos desprovidos de utilidade a violência, a festa, o jogo, o sexo sem finalidade de reprodução, etc -, isto é, despesas sociais nas suas modalidades particulares. A heterologia assume assim nítida perspectiva sócio-antropológica ao propor não somente mostrar o que é deixado de lado, desprezado - a vida improdutiva -, mas também trazer uma ordem de compreensão ao conjunto dos fenômenos que a mentalidade produtiva desconsidera.

Na proposta do Monumento Bataille fica evidente a sustentação da "irrealidade prática" do dejeto, ou seja, do corpo estranho que não se converte em forma acabada, que não se dispõe ao consumo racional ou estético. Hirschhorn sabe que em lugar da doentia obstinação da vontade em se representar um mundo homogêneo e servil, Bataille sempre preconizou uma "prática da escatologia intelectual" a comandar a "dejeção dos elementos inassimiláveis" (BATAILLE, 1970b, p. 64). Assim, à sua maneira, Hirschhorn renova a figura da despesa graças à qual podemos ficar fora de controle, tanto o artista ("eu quero me gastar") quanto o espectador. A arte abriga o incomensurável tanto quanto o incompreensível. Trata-se, portanto, de dinamizar o racional valorizando o singular e a exceção. Razão porque no Monumento Bataille a questão central era aquela do dom. O dom suspende a voracidade dos predadores financeiros e dos situacionistas da arte; está associado à celebração e, portanto, ao desperdício prazeroso. Contra a mesquinhez universal, o dom aponta para um diverso senso de comunidade. $\mathrm{O}$ presente se torna crítico, divergente, e, assim, reúne Bataille e Hirschhorn nos limites das formas disciplinares de cada linguagem. A arte mostra-se associada a uma luta que requer sacrifícios para escapar do mundo lucrativo e questionar os valores dominantes do trabalho, da economia capitalista, da razão tecnocrática e da razoabilidade que achatam a vida.

No Monumento Bataille, uma escultura, na parte externa, repensava o lugar público da arte memorialista (fig. 6). Nada ali é explicito do pensamento de 
Bataille e de sua figura. A obra se sustenta das transferências que propõe, bem como sa irresolução que a permeia. Evita-se o sentido dos sentidos, do baixo ao alto; suprime-se a implicação rígida da visão: entrega-se o monumento aos agentes (pueris) de uma desimpedida troca com a urbanidade do entorno.

Eu queria fazer uma interpretação escultural que lembrasse um tronco de árvore, uma forma orgânica, sem começo nem fim. Queria fazer uma escultura na qual o elemento orgânico fosse ocupado por uma forma geométrica ou na qual o elemento geométrico fosse o pedestal do elemento orgânico e assim, e ao mesmo tempo, impedisse que ele se conectasse à parte verdadeiramente orgânica (o chão) (HIRSCHHORN, 2000, s.p.).

Figura 6 Thomas Hirschhorn. Monument Bataille, [escultura do exterior], 2002. Documenta 11, Kasse Fonte: https:// www.ufrgs.br/ arteversa $/ p=753$

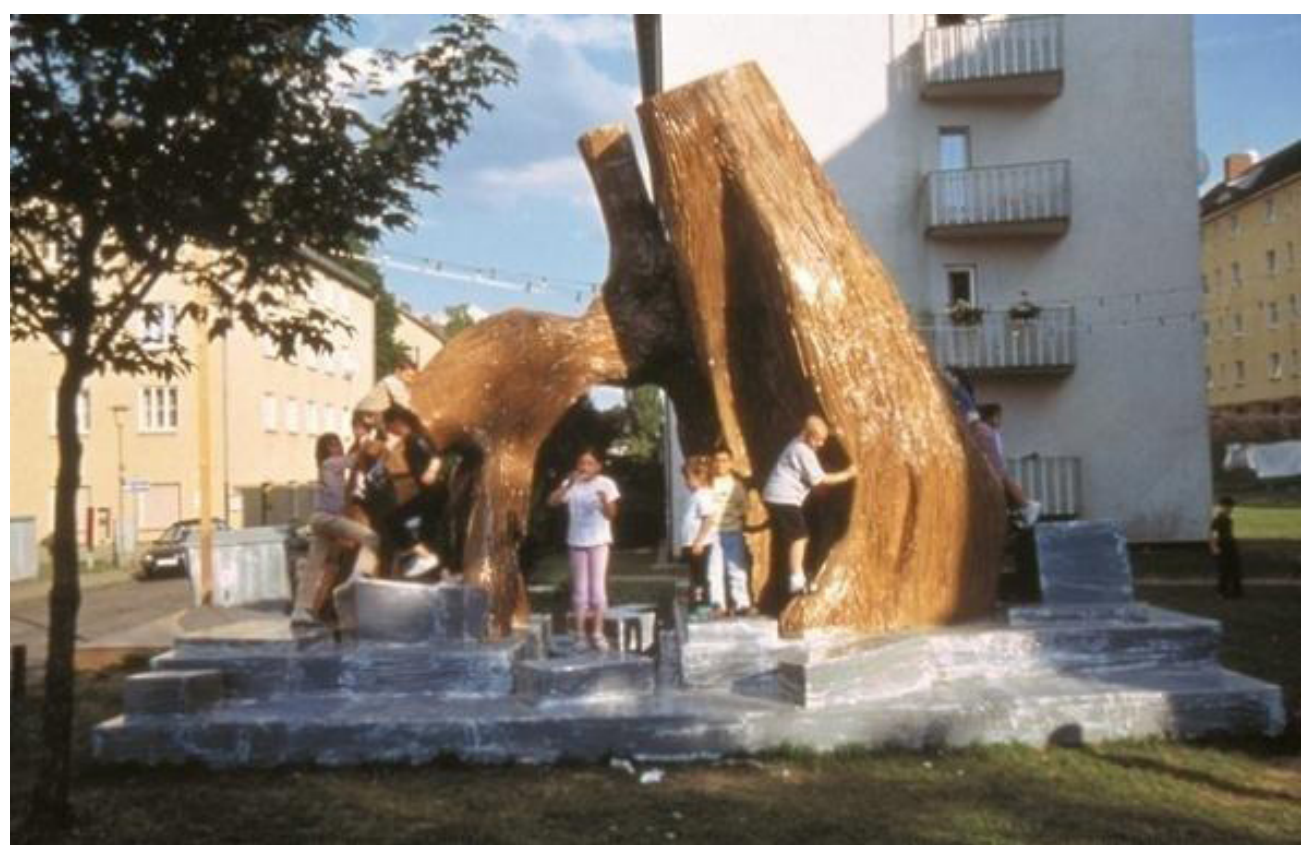

Precário parece, de imediato, designativo que aponta para a fatura insegura, rústica, e para a limitada duração das obras. Entretanto, não se passou muito tempo para que Hirschhorn entendesse que em seu trabalho o precário é menos uma característica própria quanto uma situação focalizada, com ramificações éticas e políticas. Essa situação pode ser, de imediato, vislumbrada em uma obra como Les plaintifs, les bêtes, les politiques. Ali, displays dão o tom assumido pelas palavras. Se na obra proliferam dizeres como "Eu realmente não entendi!", é porque o tom lamentoso é um dos registros do precário, como analisa Foster (2011, s.p.). Por outro lado, com a mesma frequência, Hirschhorn fala pela voz do tolo, do estúpido. "Ajudem-me a entender!" é um grito também recorrente em Les plaintifs, les bêtes, les politiques (figs. 7 e 8 ), e o sentimento não é gratuito. Hirschhorn 
Figuras 7 e 8 Thomas Hirschhorn, Les plaintifs, les bêtes, les politiques [escritos em papelão], 1995 explica que suas colagens nasceram de uma "necessidade existencial" de compreender. Não obstante a posição pretensamente "débil", Hirschhorn encontra "uma força explosiva, uma chave de resistência"; e nos recorda que é de baixo que surge a subversão. Lição que já estava em Bataille, em seu empenho em rebaixar os saberes ao nível do documento mais anódino. "Dar uma forma ao precário" é testemunhar a "fragilidade da vida", sustenta Hirschhorn (apud FOSTER, 2011, s.p.), e a consciência dessa fragilidade "me leva a estar desperto, a estar presente, a estar atento, a estar aberto; me leva a estar ativo".
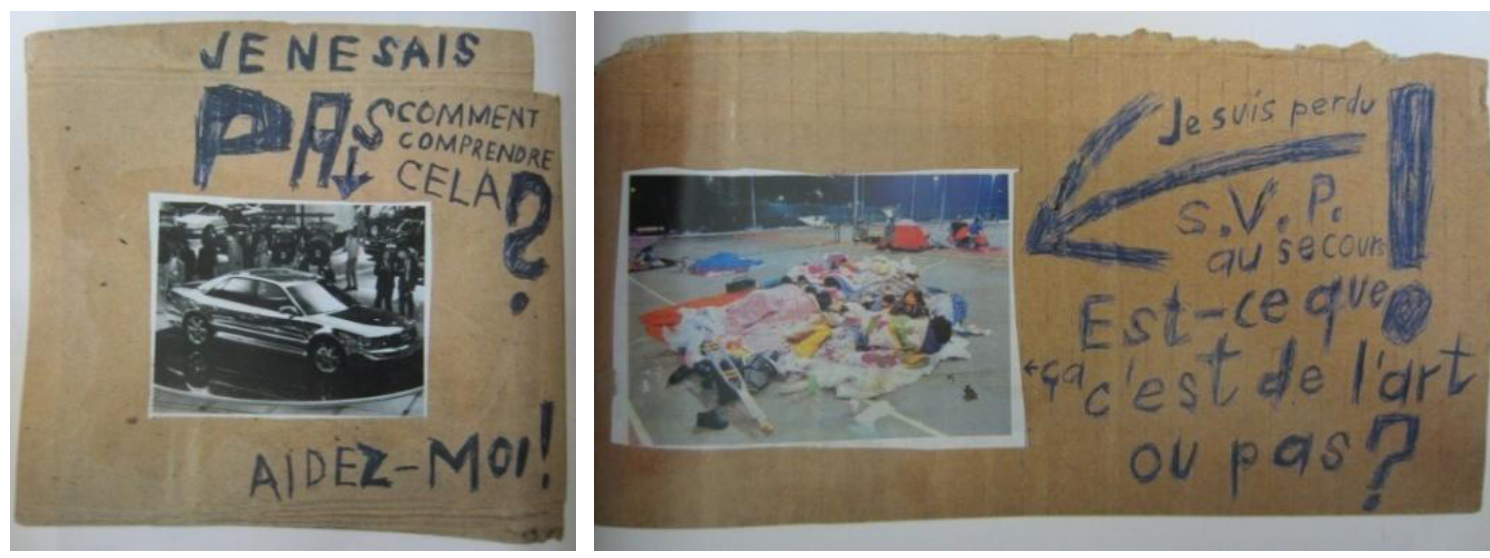

O tom de súplica que assume a palavra, contundente em muitos projetos de Hirschhorn, pode também evoluir para a acusação, quando então a dimensão política do precário imigra inequivocamente para o ético. A sugestão lhe vem das placas de pedintes na rua e no metrô, "placas de papelão feitas por pessoas em situações de necessidade existencial que adotam uma forma que é econômica, eficaz, bonita. [...] São bonitas porque combinam a linguagem do compromisso com a da sinceridade. O resultado é puro" (apud FOSTER, 2011, s.p.). A força do precário se assume, então, "frágil, cruel, selvagem, mas livre".

Se a fraqueza é um dos aspectos do tonto, outro é a "falta de cabeça", um conceito que Hirschhorn adaptou da acefalidade proposta nos anos 30 por Bataille. Hirschhorn frequentemente aponta para o caráter comumente irrefletido, espontâneo, de seu trabalho - um "agir conscientemente na precipitação". Mas ele também encontra um "caráter resistente" nessa falta de cabeça, nessa precipitação inconsequente, que descreve como uma posição "completamente submersa, mas ainda não resignada, não reconci- 
liada e (é claro) não cínica" (HIRSCHHORN, 2009-10, s.p.). Seja como for, a assumida estupidez do artista é um modo não intelectualizar em demasia o trabalho da arte em face das opacidades do mundo. Sugere que uma maneira de armar a visada é "parecer tonto", ou seja, admitir que amiúde estamos "mudos de assombro" pelos vergonhosos acontecimentos do mundo, como o assassinato de civis durante a Guerra do Iraque, presente em horrendas imagens em seu Ur-Collages (2008). Sob essa luz, parecer tonto é uma forma de ver que tem força tanto ética como política - as colagens, ainda que ditas "primitivas", canhestras mesmo (modelos do mundo fashion ao lado de corpos dilacerados da guerra), passam por ser "evidências". Elas são fruto de protocolos de busca por um "público não exclusivo", um público não conivente com a aparente dissolução da esfera pública.

"Na arte, a verdade só pode ser conduzida com falta de cabeça, em encontros fortuitos, contraditórios e ocultos" (HIRSCHHORN, 2006). O que dá a entender um principio de partilha real das condições de risco social vividas pelo precarizado em uma situação concreta. À comunidade benevolente imaginada pela estética relacional, Hirschhorn responde com o princípio "Presença e produção", que dá nome a seu compromisso de estar plenamente presente no local onde produz seu trabalho. Ele reconhece que o resultado pode levar tanto ao antagonismo quanto à comunhão com os participantes e seus modos de agir. Seja como for, Hirschhorn atualiza os argumentos de Benjamin em "Autor como produtor" (1934), onde o valor de uso político de uma obra é dito residir menos em sua atitude ou tendência do que em sua posição ou função no interior de um modo de produção.

\section{Soberania na inutilidade}

Didi-Huberman lembra como, de Siegfried Kracauer e Theodor Adorno a Guy Debord, as análises críticas não cessaram de fustigar a gestão publica das palavras e das imagens (das formas em geral), a fabricação de valores coletivos que se acostumou nomear "indústria cultural", ampla exploração a fins invariavelmente orientados (DIDI-HUBERMAN, 2017, p.94). Razão porque ele chama a atenção ao modo como Bataille levantou, em 1956, a questão do contexto político e social da cultura, contexto que motivou a perspectiva de La Part maudite.

Inequívoca afirmação de Bataille: só há autêntica cultura vinda do baixo, 
do que ele chama povos "primitivos" ou "arcaicos". Modo de subverter a significação instrumental, burguesa, de cultura. Modo de suscitar a questão que aponta para consequências políticas: como os artesãos e destinatários da cultura são tomados em relações de poder quando estas se opõem à "autonomia da cultura"? Quando impera uma tendência ao utilitarismo, uma "política da cultura" só se sustenta na denúncia do que Bataille diz ser um "equívoco da cultura", ou seja, sua implicação no jogo dos poderes de Estado e do capitalismo. Assim, uma "afirmação do homem como fim" deve combater toda acepção da cultura como meio. Se importa dar um fim ao homem, é caso então de erigir um "humanismo inteiro". Ora, esse não pode ser outro que um humanismo ferido, incongruência tipicamente batailliana, pois que focalizaria imperativamente o homem em sua incompletude. Eis o paradoxo: a soberania somente ocorre em um estado de não poder; mas se mostra inestimável quando ocorre sem cálculo, sem valor de troca, ou seja, como inapropriável (DIDI-HUBERMAN, 2012, p.44). Razão porque essa soberania não pode obedecer às relações sociais do trabalho e da servidão. O que a sustenta só pode ser uma cultura paradoxal do que se destrói como obra útil para afirmar seu "fim soberano". Um "humanismo mais inteiro" não sublima algo para torná-lo aceitável, para dotá-lo de dividendos de ocasião.

Didi-Huberman lembra como é sutil a posição batailliana, de fuga da "ternura do Estado" por "sua" cultura. Bataille chama isso "subversão": "uma inversão dos valores, [...] um movimento violento traduzido na coerência calma da linguagem" (BATAILLE, 1988, p.450). Nesse sentido, não há porque se furtar ao juízo: Hirschhorn é um transgressor com palavras rascunhadas em papelão barato.

\section{Arte política}

Nessa perspectiva, o que seria, afinal, uma arte política? Valeria, aqui, a distinção de Hirschhorn: fazer arte politicamente e não arte política. Fazer arte politicamente significa empreender uma política de escolha dos materiais, dos lugares de implantação, etc. É a maneira de fazer arte fora dos circuitos de uma política da arte. Graças à invocação de Bataille, Hirschhorn não seguiu o caminho conformista das belas-artes. Suas instalações mostram a profusão de gastos, mas não de consumo, a alegria e mesmo a embriaguez das formas, o excesso sobre a razão, a ausência de hierarquia, o descentramento do espaço de exibição, o jogo cerrado da forma e do informe. A luta é 
contra todo fechamento, conclusão ou definição bem-sucedida. Felizmente, o artista admite, a arte escapa ao controle o tempo todo. O espectador também nunca tem controle sobre o que o artista lhe apresenta, especialmente porque o que se apresenta é um processo inacabado. Um fato: a obra transmite uma energia destinada a intensificar o desejo de viver em comum.

Bataille apontava, no fim das contas, para a impossibilidade da soberania. Não por acaso, Hirschhorn fala do Musée Précaire Albinet, sua iniciativa quiçá mais audaciosa, como uma impossibilidade, para além do mero balanço entre sucesso e fracasso. Os termos são praticamente bataillianos na afirmação de uma "violência da transgressão do horizonte", de seu caráter necessariamente excessivo:

[...] A missão do Museu Precário Albinet é uma missão impossível, uma vez que esta missão impossível se baseia em um acordo. Concordar significa concordar com a missão de alguém. Somente se eu concordar com a minha missão é que posso cooperar com a realidade e mudá-la. A realidade não pode ser mudada a menos que você concorde com ela. Concordar é uma afirmação. Afirmar algo não significa respeitar algo, afirmar algo significa amar algo. O Museu Precário Albinet é uma afirmação, de acordo com o bairro, seus habitantes, sua localização, seu programa, seus visitantes, suas atividades. Concordar não significa aprovar, significa ousar ir além do horizonte da discussão, da argumentação, comunicação, justificação e explicação. O Museu Precário Albinet afirma ser um avanço. O Museu Precário Albinet carrega em si a violência da transgressão do horizonte. Eu próprio devo lutar constantemente contra a ideologia do possível e contra a ditadura do que é permitido. Eu próprio devo trabalhar contra a lógica da administração da cultura de facilitar as coisas. Eu devo constantemente me encorajar. Devo me encorajar a tomar a decisão certa e devo me manter livre. 0 Museu Precário Albinet é um projeto que não quer acalmar nem se acalmar. Com este projeto, quero ousar tocar o que não pode ser tocado, o outro, não quero neutralizar o outro. O Museu Precário Albinet não trabalha para "justiça”, "democracia”, nem para "o possível". A liberdade do artista ou a autonomia da arte permanecem palavras se o que eles pretendem é prescrito ao mesmo tempo. O Museu Precário Albinet é um projeto em excesso de trabalho, em total exagero. Este projeto deve afirmar constantemente sua razão de ser e está constantemente defendendo a autonomia de uma obra de arte. A cada dia, o Museu Precário Albinet deve ser reconstruído. Este projeto envolve complexidade, contradição, dificuldade e beleza. Nunca direi que o Museu Precário Albinet é um sucesso, nem direi que é um fracasso (HIRSCHHORN, 2004, s.p.).

\section{Uma conjuração sem cabeça}

"É tempo de abandonar o mundo dos civilizados e sua luz. É demasiado tarde para procurar ser razoável e instruído - o que levou a uma vida sem atrativos. Secretamente ou não, é necessário nos tornarmos outros [...]" (BATAILLE, 1970a, p.443). Este convite a uma tresloucada conjuração, de inequívoca inspiração nietzschiana, em certa medida dá o tom do programa assumido por Bataille para a revista Acéphale, que ele dirigiu a partir 
de junho de 1936 junto com Georges Ambrosino e Pierre Klossowski. No primeiro número da publicação são esboçadas as bases de uma conjuração contra os tempos presentes. Na sequência, Acéphale evocaria o sacrifício, a loucura, a guerra e a morte, sempre sobre as bases de uma nietzschiana "decomposição e recomposição dos valores sagrados", modo de revogar o "mundo da vulgaridade instruída", impotente diante das agitações político-sociais da modernidade.

A acefalidade é motivo central em Bataille por entender que a cabeça, autoridade ou Deus, representa funções servis assumidas como um fim, passíveis de constituir objeto da "mais viva aversão" (BATAILLE, 1970b, p.470). Em tempos de servilismos cúmplices, importa conceber sociedade diversa daquelas monocefálicas, própria a conferir "aos antagonismos fundamentais da vida uma saída explosiva", uma abertura às formas mais ricas de dispêndio (BATAILLE, 1970b, p.469). Portanto, a figura trágica e monstruosa do Acéfalo presta-se a emblematizar o modo como toda soberania se destina à destruição. O princípio da cabeça sendo a redução à unidade, seja ela Deus ou qualquer valor hegemônico, sua decapitação equivale a uma liberação de sentidos, ao preço de um regime conflituoso da existência humana, sem dever de proporcionalidade e sem direito de redenção.

O Acéfalo é figura saída a um tempo do orgiástico e da tauromaquia, matéria de um sonho de comunidade impraticável. Ele figura, ainda, certo anseio de dessemelhança, pois que constitui "imagem negativa de uma loucura antimonumental envolvida no desmembramento do sentido" (HOLLIER, 1992, p. xii). À semelhança do Dionísio nietzschiano, o Acéfalo batailliano responde à função de pedra angular de um quadro imaginário de rebelião contra as formas de identidade, que aguarda sua hora para falar aos aterrorizados da atualidade. Seu sentido íntimo: fazer da existência uma festa para além da angústia (BEAUCAMP, 2012, p.70). O Acéfalo é corpo disfuncional, des-organicidade; por isso mesmo, paradigma visual do inverificável, do não hierarquizado, contrafação de toda empreitada daquele que retém o ser humano como forma ou sentido definível.

Havia em tudo isso a expectativa de suscitar um saber visual que decompusesse o dispositivo usual da representação, invariavelmente redutível a sentidos fechados, quando não a condenáveis lirismos ou abstrações. A representação da acefalidade participa ainda de um esforço em repensar a vida em comum a partir de imagens que a demovam de sua inércia. Donde a reposição em cena de um tempo extático, catastrófico: "tempo-explosão", diverso do tempo das significações do saber, pois que relativo à existência 
concreta em suas insignificâncias. A imagética que tal visão acionava se prestava a repensar a comunidade dos homens nos momentos que antecediam a hecatombe da guerra, assim como os protocolos de uma experiência interior fundada em certa sacralidade sacrificial. Ambos os esforços se interpenetravam numa frente comum em favor de representações de uma "negatividade sem utilidade", de uma "insignificância sem apelo" (BATAILLE, 1979, p.76), representações que nem a filosofia nem a arte pareciam aptas a reconhecer.

O homem da negatividade põe em jogo representações carregadas de valor pático, tais como a destruição física ou a obscenidade erótica. Os objetos do riso, da excitação física, do medo e das lágrimas se misturam numa heteronomia do catastrófico. Contudo, ao mesmo tempo em que essas representações intoxicam - Bataille mesmo reconhece que "uma comunidade [de acéfalos] é impossível" (BATAILLE, 1976, p.377) -, ele as livra da ganga na qual elas sempre estiveram e as situa objetivamente "no desencadeamento dos tempos contra todo imutável" (BATAILLE, 1995, p.79-80).

Rosalind Krauss (1996, p.247) lembra que Bataille falava, naquele momento, para um Lumpenproletariat absolutamente não representativo, de modo a impostar a analogia entre o alto e o mais-baixo-que-o-baixo, no colapso de toda oposição dialética. A seu modo, Hirschhorn renova esse encontro com o precário a partir do baixo. Trabalhar para o outro é trabalhar para aquele a quem não se pensava e que não se esperava: uma "audiência não exclusiva"; "não simplesmente 'todos', 'a massa' ou 'a maioria', [... ] um público não exclusivo" (HIRSCHHORN, 2010, s.p.). Como se viu, uma heterologia (ciência do que é Outro) era empregada por Bataille em chave política, de modo a preconizar o "reviramento da ordem estabelecida" por meio das baixas camadas sociais, a ação revolucionária de uma "velha toupeira" em escavação por subsolos pouco recomendáveis (BATAILLE, 1970c, p.93). Encontra-se aqui, de certo modo, o leitmotiv de uma visão política da arte contrária a seu culto burguês, ao qual Hirschhorn se mostra plenamente devedor.

\section{Entropia, gasto, igualdade}

Em outubro de 1929, Bataille publica em Documents um verbete de seu "Dicionário crítico" com o título "Poeira". Ele assim terminava: "Um dia ou outro, é verdade, a poeira, posto que persista, começará provavelmente a 
ganhar vantagem sobre as domésticas, invadindo imensos escombros de construções abandonadas, de estaleiros desertos, e, nesse futuro distante, nada subsistirá que salve os terrores noturnos: pela falta dos quais nos tornamos tão grandes contábeis" (BATAILLE, 1970d, p.197).

Alegórica narrativa de um "pesadelo entrópico", no dizer de Rosalind Krauss (1996b, p.98), neste verbete Bataille trata do sentimento de decomposição como inerente aos novos tempos. O movimento das formas é inequivocamente entrópico. A noção de entropia, como se sabe, refere o processo transformador a que se submetem os elementos do mundo. As matérias se desgastam porque necessariamente perdem energia ao longo de certo tempo. Nesse processo, a imagem da poeira representa uma moderna vicissitude: o caráter agressivo dos tempos presentes que reviram os valores constituídos leva-os a apressada usura. Um movimento de basculamento aqui se caracteriza: da preservação ao dispêndio, do armazenamento à dispersão, de uma forma tectônica a outra extática. Movimento de gasto que inevitavelmente acompanha toda produção arquitetada pelo homem ("imensos escombros de construções abandonadas, de estaleiros desertos"). Entrópica proliferação da usura, que atinge mesmo os valores pequeno-burgueses, assimiláveis a fantasmas em sua rançosa inconsistência.

Uma significativa ilustração acompanhava o texto de Bataille: a fotografia de um porão de museu aponta para o ritmo inevitável das catástrofes do tempo, com o acúmulo de objetos de um derrisório mimetismo antropomórfico em evidente desuso, ou caídos em desgraça junto ao gosto vigente. A fotografia funciona, ainda, como uma metáfora visual das mutações da psique. O museu não deixa de ser imenso espelho no qual o homem se contempla em todas as faces, "onde se vê literalmente admirável e se abandona ao êxtase expresso em todas as revistas de arte" (BATAILLE, 1970d, p.240). Bataille não deixa, contudo, de lembrar a filiação do museu ao Terror, à morte violenta e ao desmembramento, por decapitação. É o que ele pretendia insinuar com a imagem dos "bastidores" do belo: "restos do moderno inconsciente - composto de partes desmembradas, envolvido em poeira, como um filme ou uma tela que a um tempo reveste e obscurece as formas sólidas, decompõe-nas e estilhaça-as". O inconsciente da arte, por assim dizer, deixa-se emblematizar nos jogos de alteração das formas.

Em sua introdução à reedição de Documents, Hollier observa como a vanguarda de uma época de resistência ao formalismo modernista dos anos 1920 é animada pelo desejo de um retorno, e até mesmo de uma regressão, ao 
que se poderia chamar de "primitivismo do valor de uso" (HOLLIER, 1992, p.283). Essa regressão visaria romper com o desvio a que todo objeto de apreciação é submetido: abstraído de seu contexto de uso, ele invariavelmente se vê submetido a um sistema de equivalências que lhe concede um estatuto formal, sua mais valia estética, à prova do tempo. Os etnógrafos pertencentes ao grupo de Documents, ao deplorarem a estetização dos objetos primitivos, priorizaram seu valor de uso; mesmo porque, inerente à materialidade, ele não sobrevive a seu consumo, isto é, a sua destruição. Assim, conclui Hollier, "a consideração do valor de uso implica [...] estar no nível mesmo do objeto", isto é, da "heterogeneidade introcável de um real" (HOLLIER, 1992, p.287).

A insistência no valor de uso é o traço mais característico da iconoclastia sem dividendos de Bataille. Ela permite entender melhor o alcance crítico das propostas de Hirschhorn. Sua opção pelos dejetos, pelos grafismos de urgência, pelos manequins de certa desolação dadaísta, parece refletir a obsessão pela usura e pelo precário. Acompanha tal obsessão particular aritmética: "Eu acho que mais é sempre mais. E que menos é sempre menos", afirma Hirschhorn em uma polêmica contra a estética moderna de "menos é mais". "Mais é mais, como fato aritmético e como fator político. Mais é maioria. Poder é poder. Violência é violência. Eu também quero expressar essa ideia no meu trabalho" (HIRSCHHORN, 1995, s.p.). Ocorre, por fim, que seu trabalho pela implicação do outro proponha um potlatch igualitário: "É urgente trabalhar e mostrar que a arte - porque é arte - pode criar um diálogo ou uma confrontação de um a um e de igual a igual" (HIRSCHHORN, 2020 , s.p.). O dom teorizado por Mauss permanece pano de fundo: "em lugar de provocar a participação da audiência, quero que se implique [...] Eis o intercambio que proponho". "Sou eu, como artista, que tenho de dar primeiro". "A participação só pode ser um afortunado resultado, porque eu, como artista, tenho que fazer o trabalho de implicação do outro" (HIRSCHHORN, 2020, s.p.).

O jogo visa cristalizar um tipo de comunidade diversa, ainda que momentânea. Um relacionamento com o outro aberto a riscos de que a arte não pode resgatar. Essa sempre foi a orientação de Horschhorn: "criar - através da arte - uma forma que envolva o outro, o inesperado, o desinteressado, o vizinho, o desconhecido, o estrangeiro" (HIRSCHHORN, 2010, s.p.).

É digna de nota, a respeito, a observação de Foster: no potlatch, o prestígio se acumula naquele que pode gastar mais; donde o acúmulo de poder sim- 
bólico evidente em artistas como Beuys, Warhol e, mais recentemente, $\mathrm{Ai}$ Weiwei. "Isso ocorre em menor grau em Hirschhorn, que procura aquela coisa oximorônica que é o potlatch igualitário - ' 1 homem $=1$ homem' é outro de seus lemas" (FOSTER, 2011, s.p.). Isso representa, porém, seu próprio estado de emergência, para o qual assume variegada persona: "lutador solitário", "guerreiro", "pensador", "testemunha”, etc. Não surpreende, pois, que, em pleno estado de isolamento social pela pandemia da Covid-19, Hirschhorn faça desfilar pela tela, cartaz por cartaz, seus truísmos, como uma espécie de Bob Dylan das artes visuais: "Arte", "Rigor", "Verdade", "Prazer", "Mistério", "Extremismo", "Morte" e assim por diante (figs. 9 e 10). Na mesma oportunidade, diante da excepcionalidade e urgência do momento, Hirschhorn reafirma sua posição quanto à necessidade para o artista de tomar posição, assumir sua vontade e passar à ação de "dar forma".

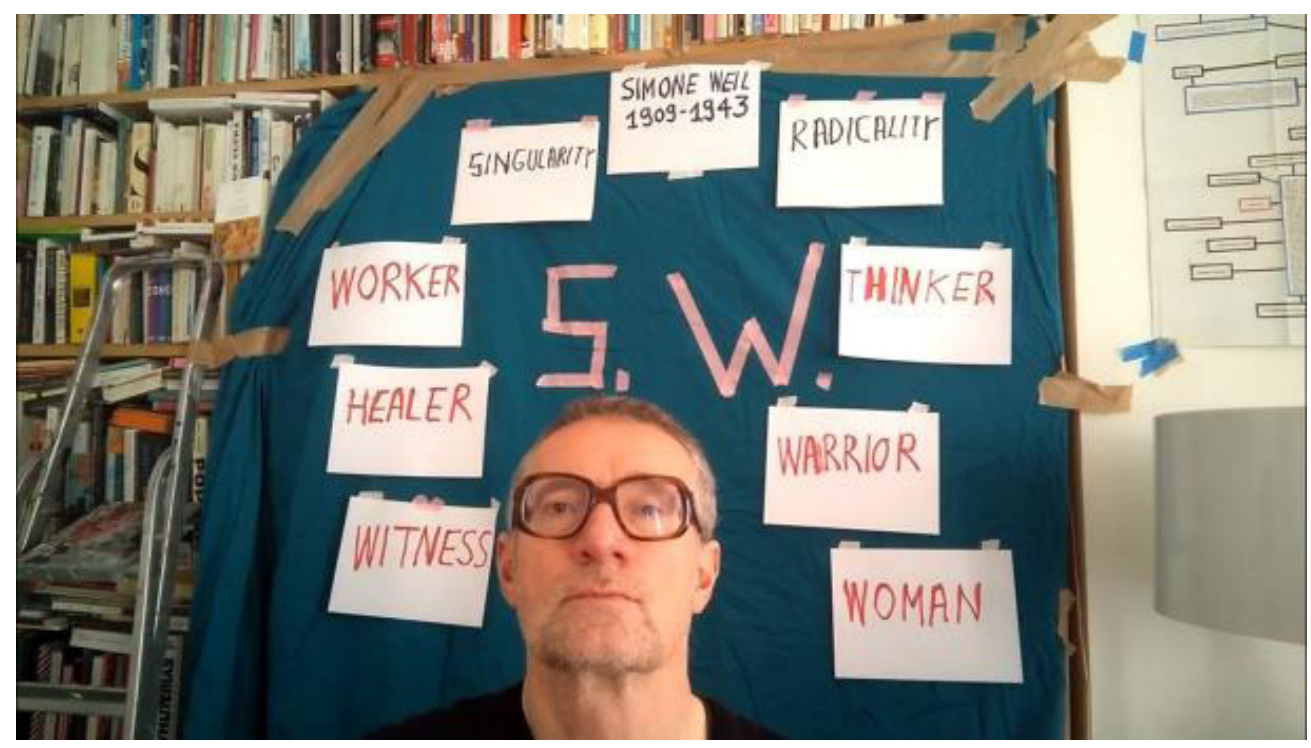

Figura 5 Thomas Hirschhorn Me, She, abril. 2020 (frames) Fonte: https:// www.youtube.com/ watch?time contin$\mathrm{ue}=17 \& \mathrm{v}=$ ZEt $82 \mathrm{UcEO}$ qc\&feature=emb_logo

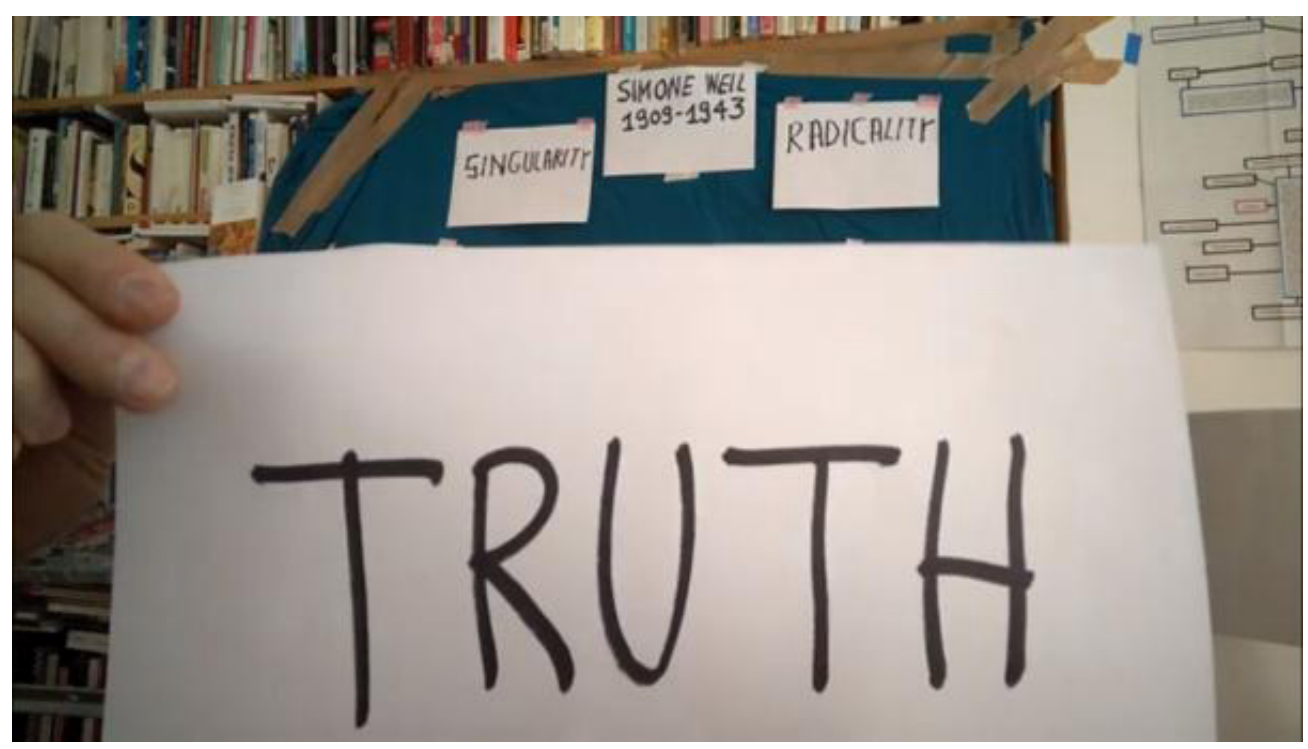


Nos tempos atuais, "compromisso" e "autonomia" não estão em contradição (como é caso, comumente, no discurso estético em geral), porque a autonomia que interessa a Hirschhorn não é dada pela autossuficiência da arte ou pela especificidade dos gêneros ou meios apregoada pelo modernismo, mas a autonomia de um "campo alargado da arte", para reter um dos pressupostos que movimentam a acepção do artista em Hirschhorn. Sua obra, é caso de reafirmar, já não corresponde à ideia tradicional de trabalho artístico com suas noções herdadas da estética romântica (o gosto, a emoção estética, a aura do artista, a unicidade da obra, o processo criador). A imagem tece-se na textura material da vida, ao desabrigo de suas idiossincrasias.

Minhas linhas de conduta são: "Agir sem cabeça"; "Energia = sim! Qualidade = Não!"; Se enfraquecer - mas fazer um trabalho poderoso; Permanecer vulnerável e ao mesmo tempo ser soberano: Não se economizar - se gastar; "Panic is the solution!"; Ser preciso e exagerar; Se aito-erigir; se autorizar; Ser cruel com meu próprio trabalho; Ser determinado; "Less is less! More is more!"; Saber que na arte nunca há sucesso total, mas também nunca há fracasso total; Perguntar-me: posso - com meu trabalho - criar um novo conceito em arte? Assumir a responsabilidade por tudo relacionado ao meu trabalho; "Melhor é sempre pior"; Recusar todas as hierarquias; Pensar em Joseph Beuys e sua frase: "Todo ser humano é um artista", ou ainda a frase de Andy Warhol: "Don't cry - Work!" (HIRSCHHORN, 2010, s.p.).

\section{Um artista para a condição pós-crítica?}

Em conversações com Rancière, entre 2009 e 2010, Hirschhorn explica sua linha de conduta "Presença e Produção", o consequente trabalho com os que estão à margem e a criação de um "tempo ou momento de espaço público". Ele então se pergunta se o condicionante de sua proposta não estaria igualmente à margem de sua figura de artista. Uma vez assumida a igualdade do "tempo em demasia" dos inativos, a quem Hirschhorn endereça seu trabalho (Monument Bataille), e a precariedade de seu projeto (The Bijlmer Spinoza-Festival), ele se pergunta: a presença da obra permite "um espaço novo no qual o 'tempo em demasia' [pode] se cristalizar e tomar uma forma"? "Uma relação precária é suficientemente densa para criar um real acontecimento"? O protocolo "Presença e Produção" é, por fim, assumido como "um dom ofensivo, mesmo agressivo" (HIRSCHHORN \& RANCIÈRE, 2009-10, p.130).

Em sua resposta a Hirschhorn, Rancière não deixa de ressaltar a igualdade assumida entre "presença" e "produção". "Igualdade, de imediato, entre 
dois modos de presença que é costume opor: a presença da obra como resultado do trabalho do artista, proposta a espectadores, e a presença do artista como portador ou iniciador de uma ação". Em sua conhecida aversão à arte relacional, Rancière sabe como, sob cobertura de uma desmistificação, radicaliza-se a figura tradicional do artista, incapaz de se desfazer da relação consigo para se liberar "ao exame e à temporalidade de outros" (HIRSCHHORN \& RANCIÈRE, 2009-10, p.130). Em Hirschhorn, como se viu, o artista não se apresenta como animador, mas como produtor. E um produtor cioso da administração igualitária do tempo. Assim, o "efeito-arte" deixa de exigir o nível de envolvimento que se conhece, formalista por natureza. Porquanto fale a marginalizados, àqueles que têm "tempo em demasia", o trabalho de Hirschhorn não concorre a uma "comum posição à margem", o que infirmaria certa mística do artista. Antes, ele promove nítida "porosidade da linha de partilha", uma circulação entre o tempo ocupado e o tempo desobrado "que todas as formas atuais de precariedade e de intermitência tornam mais sensíveis" (HIRSCHHORN \& RANCIÈRE, 2009-10, p.132). A potência política da arte residiria nesse particular: mais que ensinar, demonstrar, provocar ou mobilizar, propor a mutualidade dos modos, "tocar a distribuição normal dos tempos e dos espaços" (2009-10, p.135). O que equivale a se abrir à "incomensurabilidade de uma situação complexa", sem garantias, sem mais valia patenteada por alguma razão cínica, complementa Hirschhorn (2009-10, p.133).

Quanto à arte crítica, ela é comprometida por sua própria dependência da desmistificação. "Na sua expressão mais geral", sustenta Rancière, "a arte crítica é um tipo de arte que propõe construir a consciência dos mecanismos de dominação a fim de tornar o espectador um agente consciente de transformação do mundo" (RANCIÈRE apud FOSTER, 2013, p.169). No entanto, não somente a consciência não é transformadora per se, Rancière continua, mas "os explorados raramente exigem uma explicação das leis da exploração". Além disso, a arte crítica não cessa de solicitar dos espectadores que descortinem os signos do capital por detrás dos objetos e comportamentos cotidianos. Ao fazê-lo, contudo, ela apenas confirma "a transformação das coisas em signos" promovida pelo capital. Razão porque o artista crítico, conclui Rancière, está preso em um círculo vicioso.

Talvez ele concorde com a crítica que Foster move contra a dita virada antropológica do artista (FOSTER, 2014, p.168 sgg.). Mesmo porque, seguramente, esta é a razão porque ele enaltece a ética da generosidade 
própria à obra de Hirschhorn. Não há no artista suíço nenhuma prerrogativa de didatismo antropológico em relação aos estados de precariedade. Não há nem mesmo auto-indulgência altiva em relação a eles. $O$ interlocutor de Hirschhorn não é o espectador passivo com necessidade de ativação, o ingênuo necessitado de desmistificação.

Isto posto, fica-se com a interrogação sobre a inscrição de Hirschhorn num processo de reapropriação da arte pública em seu assento político, para além do mecenato próprio às artes relacionais. Foster perguntava, em 2012, sobre o destino da arte crítica após as "ações simbólicas" dos anos 80, mais situacionistas do que produtivistas, como estima Foster (2014). Ele respondia destacando duas posições possíveis: por um lado, haveria a posição "quase gramsciana" da arte ativista que, com o beneplácito da aliança entre crítica e capital, vê um campo amplamente aberto para o rebatimento da arte nas práticas sociais. Por outro lado, há a posição "quase adorniana", que insiste em se manter na categoria estética de arte, mas com a sensação de ter pouco a fazer além de prosseguir nas propostas formalistas. Em face dessas suas possibilidades, como situar a posição de Hirschhorn? Uma Forma autárquica que anseia por ocupar o palco sempre disponível das práticas sociais? Ou uma Forma como negatividade que se quer ativa, nunca meramente reativa, nada solidária dos formalistas defuntos da arte modernista?

Em seu livro de 1996, O retorno do real, Foster apontava para as projeções dos artistas sobre a figura do etnógrafo dos estudos culturais e sua ciência da alteridade. Estas projeções encenam uma vez mais o "mito do artista redentor", e o faz recair na duplicidade da razão cínica: ele conserva o "status social da arte" ao mesmo tempo em que exerce a "pureza moral da crítica" (FOSTER, 2014, p.174 e 180). Nas últimas duas décadas, adverte Foster, o artista etnográfico se sentiu particularmente atraído pela atuação junto a comunidades localizadas. Foster acredita que isto pode levar a uma redução identitária de ambos: "obras site-specific correm o risco de descair na política de identidade tout court" (FOSTER, 2014, p. 182). O risco seria de redução do modus operandi do artista: um uso essencialmente funcional do outro para fins, uma vez mais, de vanguardismo das formas. Pelo que se expôs aqui, essa investida de Foster contra a inflexão etnográfica na arte contemporânea não parece incluir um artista como Hirschhorn. Reiteradas vezes Hirschhorn afirmou como o Museu Precário Albinet não era um projeto sócio-cultural, e como ele não era "controlável", que poderia escapar a qualquer momento ao politicamente premeditado - ou a sua absorção por uma promoção político-cultural oficial - por justamente estar sob a tutela 
da própria comunidade a que servia. Talvez se possa admitir que a obra de Hirschhorn é tributária das novas conexões discursivas que tornam a arte contemporânea "perigosamente política", como receia Foster (2014, p.185) - e que a fazem passar para o campo ampliado da cultura. Contudo, não parece que ela concorra a mistificar as posturas críticas. Seja como for, há uma evidência: nenhum artista neovanguardista avançou tanto quanto Hirschhorn no intento de fazer da coletividade a própria questão em jogo de um projeto artístico, para além de todo hermetismo ou narcisismo da Arte. Em seu trabalho, o "pôr em forma" é um processo aberto, imponderável, caótico, que não termina no objeto, que não se retira aos recintos ritualizados da Instituição; pelo contrário, nascido no fazer da vida, abre-se à ação e ao mundo.

\section{Referências}

BATAILLE, Georges. La conjuration sacrée. Oeuvres complètes, vol I. Paris: Gallimard, 1970a, p.442-465.

. L'équivoque de la culture. Oeuvres complètes, vol.

XII. Paris: Gallimard, 1988, p.437-450.

. La Part maudite: Paris: Éditions de Minuit, 1949.

. L'apprenti sorcier. Le Collège de Sociologie 1937-

1939. Paris: Gallimard, 1995.

. La valeur d'usage de D.A.F. de Sade. Oeuvres Complètes, vol II. Paris: Gallimard, 1970b, p.54-69.

. La "vieille taupe "et le préfixe sur dans les mots surhomme et surréaliste. Oeuvres Complètes, tome II. Paris: Gallimard, 1970c, p.93-109.

. Poussière; Esthète; Musée. Oeuvres complètes, vol I. Paris: Gallimard, 1970d, p.197, p.236 e p. 239-240, respectivamente.

BEAUCAMP, Maxime. "Georges Bataille: Acéphale et la question de la transgression". Klesis. Revue philosophique, n² 22, 2012, p.61-74. 
DIDI-HUBERMAN, Georges. Peuples exposés, peuples figurants. Paris: Minuit, 2012.

- Quando as imagens tomam posição. Trad. Cleonice Pares Barreto Mourão. Belo Horizonte: Editora UFMG, 2017.

FOSTER, Hal. O retorno do real. Trad. Célia Euvaldo. São Paulo: CosacNaify, 2014. . Pós-crítica. Arte \& Ensaios, n² 25, ago 2013.

. Towards a grammar of emergency. New Left Review, 68, Mar Apr 2011. Disponível em < https://newleftreview.org/issues/II68/articles/ hal-foster-towards-a-grammar-of-emergency>. Acesso em 8 junho 2020.

HIRSCHHORN, Thomas. Faire de l'art politiquement: qu'est-ce que cela veut dire?, 2008. Disponível em <http://www.thomashirschhorn.com/faire-de-lart-politiquement-quest-ce-que-cela-veut-dire/>. Acesso em 8 junho 2020.

. About the Musée Précaire. Albinet, 2004. Disponível em < http://www.thomashirschhorn.com/about-the-musee-precaire-albinet/ >. Acesso em 11 junho 2020.

. Less is Less, More is More, 1995. Disponível em < http://www.thomashirschhorn.com/less-is-less-more-is-more-1995/>. Acesso em 9 junho 2020.

. Bataille Monument, 2000. Disponível em <www. thomashirschhorn.com/bataille-monument/ >. Acesso em 8 junho 2020.

. Qu'est-ce que je veux ? Quelle est ma position?, 2010. Disponível em < http://www.thomashirschhorn.com/quest-ce-que-je-veux-quelle-est-ma-position-conference-de-thomas-hirschhorn/ >. Acesso em 6 junho 2020.

HIRSCHHORN, Th, \& RANCIÈRE, J.. Présupposition de l'égalité des intelligences et amour de l'infinitude de la pensée. Entrevista com Jacques Ranciére, 20092010. Disponível em < http://www.thomashirschhornwebsite.com/wp-content/uploads/2018/02/Entretien_Ranci\%C3\%A8re_Opuscule4_2010. pdf>. Acesso em 11 junho 2020. 
KRAUSS, R. \& BOIS, Yve-Alain (orgs.). Formless: A User's Guide. Cambridge: MIT Press, 1996a.

. Down and Dirty. Lauren Sedofsky Talks with Rosalind Krauss and Yve-Alain Bois. Artforum, v. 34, $\mathrm{n}^{\circ} 10$, 1996b, p.91-95. Disponível em < https://www.questia.com/magazine/1G1-18533853/down-and-dirty>. Acesso em 7 junho 2020. 